\title{
The impact of product market competition on transactions with related parties and company performance
}

\author{
Mojtaba Asadi $^{\mathrm{a}}$, Norouz Nouralahzadeh ${ }^{\mathrm{b}^{*}}$ and Mohsen Hamidian ${ }^{\mathrm{c}}$
}

\author{
${ }^{a}$ Masters Student, Department of Management and Accounting, South Tehran Branch, Islamic Azad University, Tehran, Iran \\ ${ }^{b}$ Faculty Member, Department of Management and Accounting, South Tehran Branch, Islamic Azad University, Tehran, Iran \\ ${ }^{c}$ Assistant Professor, Department of Management and Accounting, South Tehran Branch, Islamic Azad University, Tehran, Iran \\ C H R O N I C L E

\section{A B S T R A C T}

\begin{tabular}{l}
\hline Article history: \\
Received October 28, 2014 \\
Accepted 25 January 2015 \\
Available online \\
January 272015 \\
\hline Keywords: \\
Tehran Stock Exchange \\
Product market competition \\
Competition \\
Herfindahl-Hirschman Index \\
\hline
\end{tabular}

This paper presents an empirical investigation on the effect of product market competition on transactions with related parties and company performance. The study selects a sample of 250 randomly selected firms whose common shares were traded on Tehran Stock Exchange. The study uses Herfindahl-Hirschman Index (HHI) to measure the market concentration and uses historical information over the period 2008-2012 to examine the hypotheses of the survey. Using simple regression analysis, the study has detected a positive relationship between HHI and related party transactions. In addition, the study has detected a negative relationship between competition and company performance measured by return on assets.

(C) 2015 Growing Science Ltd. All rights reserved.

\section{Introduction}

During the past few years, there have been substantial attention on the role of boards of directors in internal corporate governance, concentrating primarily on monitoring managers and in removing nonperforming chief executive officers (CEOs). According to, Jensen (1993), internal control mechanisms are relatively weak for poor managers. An essential concern, stated by Jensen (1993), is associated with insufficient independent leadership, which makes it "extremely difficult for the board to respond early to failure in its top management team', Jensen states that when the CEO also keeps the position of the chairman of the board (chairman), internal control systems may fail, as the board cannot substantially execute its key functions including those of assessing and firing CEOs. Similarly, Fama and Jensen (1983) discussed that concentration of decision management and decision control in one individual may influence on a board's effectiveness in assessing top management. Various corporate governance activists have also stated similar concerns about combining the CEO and chairman responsibilities (Chien \& Hsu, 2010).

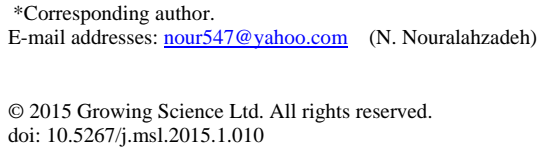


However, Brickley et al. (1997) recommended that separate CEO and chairman positions could jeopardize expenses in monitoring the chairman ('who monitors the monitor?'), information sharing expenses between the CEO and the chairman, and incentive expenses related to a succession process in which CEOs could be promised the chairman title. These expenses might also offset the monitoring advantages that could arise from a separate CEO. Comparing the performance of companies that separate CEO and chairman duties with those companies that combine them.

Chen et al. (2012) investigated the relationship between product market competition and normal related party transactions (RPT) (Cheung et al., 2009; Hwang et al., 2013) and reported a significant positive relationship. In addition, they studied the substitutive impact of product market competition and the cash flow rights owned by ultimate controlling shareholders on the extent of normal related party transactions. They reported a positive relationship between the ultimate controlling shareholders' cash flow rights and normal related party transactions, which was strongest in noncompetitive industries and weakens as product market competition increases.

Kang et al. (2014) investigated whether RPT were used as a mechanism for tunneling among companies belonging to large business groups in Korea (chaebols). They reported that the controlownership wedge was positively associated with the magnitude of RPTs. RPTs increase as voting rights increase, while RPTs decrease as cash flow rights increase. The control-ownership wedge was more closely associated with RPTs among the top 5 chaebol companies where the agency conflicts between the controlling shareholders and the minority shareholders were more severe than in non-top 5 chaebol firms. While the substantial positive association between the control-ownership wedge and RPTs holds for both operating and non-operating RPTs, they reported that non-top 5 chaebols implemented only non-operating RPTs whereas the top 5 firms implemented both operating and non-operating RPTs. Finally, they reported that RPTs of Korean chaebol firms, on average, could reduce firm value, but this value destruction was observed only when the control-ownership wedge was high and was more pronounced with the top 5 chaebol firms.

Yeh et al. (2012) explored how corporate governance influence on the level of RPTs and how it could moderate the motives of using RPTs in Taiwan, an ownership-concentrated economy. They reported that good corporate governance was effective in constraining RPTs with the negative relation being sustainable across various measures of RPTs (raw, residual and industry-adjusted RPTs) and across various kinds of RPTs (related sales, lending and guarantee, and related borrowings). They also reported that the level of related sales was positively associated with the condition that firms plan to issue seasoned equity next period and the condition of a decrease in the reported earnings. The internal capital market hypothesis indicated that the level of related lending and guarantee (related borrowing) was negatively (positively) associated with the condition of an increase in capital expenditure and an increase in net working capital.

\section{The proposed study}

This paper presents an empirical investigation on the effect of product market competition on transactions with related parties and company performance. The study selects a sample of 250 randomly selected firms whose common shares were traded on Tehran Stock Exchange. In our study, we limit the sample size only on firms whose fiscal year ends March and there was no change on their fiscal year. In addition, no financial or holding firm was permitted to sample size. The study uses HerfindahlHirschman Index (HHI) to measure the market concentration and uses historical information over the period 2008-2012.

\subsection{Variables Definition}

\subsubsection{Operating Performance}

One way to evaluate the effect of related party transactions on firm value is to study an accounting based measure of operating performance. This study uses return on assets (ROA), as dependent variable, 
calculated as net income divided by average total assets, as the measure of operating performance (Chien \& Hsu, 2010).

\subsubsection{Related Party Transactions}

Many studies adopt six types of related party transactions (RPT): (1) Related Party Sales (RPSales) measured as related party sales divided by total sales, (2) Related Party Purchases (RPPurch) measured as related party acquisitions divided by expense of goods sold, (3) Benefit on Disposal of 13 Assets from Related Parties (RPAG) measured as revenue on disposal of assets from related parties divided by total sales, (4) Loss on Disposal of Assets from Related Parties (RPAL) measured as loss on disposal of assets from related parties divided by total sales, (5) Related Party Interest Revenue (RPIR) measured as related party interest revenue divided by total sales and finally (6) Related Party Interest Expense (RPIE) measured as related party interest expense divided by total sales (Chien \& Hsu, 2010). This study uses RPT as dependent variable.

\subsubsection{Herfindahl-Hirschman Index}

The Herfindahl Index (HHI) is a measure of the size of firms in relation to the industry and an indicator of the amount of competition among them. The proposed study of this paper uses HHI as independent variable.

\subsection{Control Variables}

Some other factors impacting operating performance of a firm are included in the regressions as control variables. The control variables implemented in this study are firm size (SIZE), assets growth (GROWTH), and debt ratio (DEBT). The size is measured by taking natural logarithm of total assets, GROWTH is the ratio of market value of shares divided by book value of shares. Finally, DEBT ratio is calculated as the ratio of total firm's liabilities divided by total assets.

The study considers the following two hypotheses,

1. There is a relationship between HHI and RPT.

2. There is a relationship between HHI and ROA.

The study uses the following two regression analysis to examine the hypotheses of the survey,

$$
\begin{aligned}
& R P T_{i, t}=\beta_{0}+\beta_{1} \mathrm{HHI}_{i, t}+\beta_{2} \text { Size }_{i, t}+\beta_{3} \text { Growth }_{i, t}+\beta_{4} \text { Debt }_{i, t}+\varepsilon_{i, t}, \\
& \text { ROA }_{i, t}=\beta_{0}+\beta_{1} \mathrm{HHI}_{i, t}+\beta_{2} \text { Size }_{i, t}+\beta_{3} \text { Growth }_{i, t}+\beta_{4} \text { Debt }_{i, t}+\varepsilon i, t .
\end{aligned}
$$

Table 1 demonstrates some basic statistics associated with the proposed study.

Table 1

The summary of some basic statistics

\begin{tabular}{lccccc}
\hline Variable & Mean & Median & Standard deviation & Skewness & Jarque-Bera \\
\hline RPT & 183.39 & 134.5 & 178.3 & 1.92 & 1638.267 \\
ROA & 5.52 & 6.47 & 19.46 & -1.71 & 3273.004 \\
HHI & 0.62 & 0.66 & 0.22 & -0.55 & 74.41686 \\
SIZE & 37.90 & 21.40 & 52.61 & 4.34 & 48842.41 \\
GROWTH & 6.39 & 3.33 & 8.94 & 2.72 & 4586.185 \\
DEBT & 0.62 & 0.66 & 0.22 & -0.53 & 796060.1 \\
\hline
\end{tabular}

According to the results of Table 1 , all data are normally distributed and we can use regression analysis. Table 2 demonstrates the results of correlation among different components of the survey. 
As we can observe from the results of Table 2, there are not strong correlation among independent variables.

Table 2

The summary of correlation among various components of the survey

\begin{tabular}{|c|c|c|c|c|c|c|}
\hline Variable & DEBT & GROWTH & HHI & ROA & RPT & SIZE \\
\hline DEBT & 1.000000 & & & & & \\
\hline Sig. & ----- & & & & & \\
\hline GROWTH & -0.114961 & 1.000000 & & & & \\
\hline Sig. & 0.0000 & ----- & & & & \\
\hline HHI & 0.046861 & 0.044728 & 1.000000 & & & \\
\hline Sig. & 0.0988 & 0.1151 & ----- & & & \\
\hline ROA & -0.526221 & 0.155462 & -0.070620 & 1.000000 & & \\
\hline Sig. & 0.0000 & 0.0000 & 0.0128 & ----- & & \\
\hline RPT & 0.022906 & -0.059975 & 0.088475 & -0.155812 & 1.000000 & \\
\hline Sig. & 0.4199 & 0.0346 & 0.0018 & 0.0000 & ----- & \\
\hline SIZE & 0.078831 & -0.013688 & -0.028499 & -0.161477 & 0.351643 & 1.000000 \\
\hline Sig. & 0.0054 & 0.6299 & 0.3156 & 0.0000 & 0.0000 & ----- \\
\hline
\end{tabular}

In addition, we use extended Augment Dicky-Fuller (ADF) test offered by Phillips and Perron (1988) to find out whether the data are stationary and the results are summarized in Table 3 as follows,

Table 3

The results of extended Augment Dicky-Fuller (ADF) test

\begin{tabular}{lccc}
\hline Variable & Statistics & Sig. & Result \\
\hline RPT & 1089.49 & 0.000 & Stationary \\
ROA & 1209.09 & 0.000 & Stationary \\
HHI & 1175.15 & 0.000 & Stationary \\
SIZE & 1250.78 & 0.000 & Stationary \\
GROWTH & 1234.02 & 0.000 & Stationary \\
DEBT & 1237.20 & 0.000 & Stationary \\
\hline
\end{tabular}

Finally, Table 4 shows the results of F-Limer test and Hausman test, which in both tests, the random effects model was chosen.

Table 4

The summary of F-Limer and Hausman tests

\begin{tabular}{lccc}
\hline & Statistics & Sig. & Result \\
\hline Model-1: (Eq. 1) Limer & 2.68 & 0.000 & Panel data \\
Model-1: (Eq. 1) Hausman & 3.32 & 0.50 & Random effect \\
Model-2: (Eq. 2) Limer & 2.68 & 0.00 & Panel data \\
Model-2: (Eq. 2) Hausman & 5.68 & 0.22 & Random effect \\
\hline
\end{tabular}

\section{The results}

In this section, we present the results of regression analysis for testing two hypotheses of the survey.

\subsection{The first hypothesis}

The first hypothesis of the survey investigates the relationship between HHI and RPT and the results are summarized as follows,

$$
\begin{array}{lccccc}
R P T_{i, t} & =99.77707 & +76.17535 \mathrm{HHI}_{i, t}+1.189755 \text { Size }_{i, t}-1.115626 \text { Growth }_{i, t}-2.594551 \text { Debt }_{i, t}+\varepsilon_{i, t} \text {, } \\
\text { t-student } & 5.42 & 3.38 & 6.10 & -1.93 & -0.65 \\
\text { Sig. } & 0.000 & 0.001 & 0.000 & 0.05 & 0.51
\end{array}
$$$$
\text { F-statistics }=47.16(\text { Sig. }=0.000), \mathrm{D}-\mathrm{W}=1.93, \mathrm{R}^{2}=0.13
$$ 
As we can observe from the results of Eq. (3), there is a positive relationship between RPT and HHI. The relationship is meaningful when the level of significance is one percent. F-statistic is equal to 47.16 with Sig. $=0.000$ and Durbin-Watson $(\mathrm{D}-\mathrm{W})$ value is within an acceptable level. R-Square value is equal to 0.13 , which means the independent variables represent approximately $13 \%$ of the changes on dependent variable. Therefore, the first hypothesis of the survey has been confirmed.

\subsection{The second hypothesis}

The second hypothesis of the survey investigates the relationship between HHI and ROA and the results are summarized as follows,

$$
\begin{array}{lccccc}
\text { ROA }_{i, t} & =16.28 & -4.63 \mathrm{HHI}_{i, t}-0.04 \text { Size }_{i, t} & +0.21 \text { Growth }_{i, t}-9.34 \text { Debt }_{i, t}+\varepsilon_{i, t} \text {, } \\
\text { t-student } & 7.83 & 2.50 & -3.14 & 3.99 & -4.17 \\
\text { Sig. } & 0.000 & 0.01 & 0.001 & 0.000 & 0.000 \\
\text { F-statistics }=131.3 \text { (Sig. }= & 0.000), \mathrm{D}-\mathrm{W}=1.97, \mathrm{R}^{2}=0.29
\end{array}
$$

As we can see from the results of Eq. (4), there is a negative relationship between ROA and HHI. The relationship is meaningful when the level of significance is one percent. F-statistic is equal to 131.3 with Sig. $=0.000$ and Durbin-Watson $(\mathrm{D}-\mathrm{W})$ value is within an acceptable level. R-Square value is equal to 0.29 , which means the independent variables represent approximately $29 \%$ of the changes on dependent variable. Therefore, the second hypothesis of the survey has been confirmed.

\section{Conclusion}

In this paper, we have presented an empirical investigation to study the effects of The Herfindahl Index (HHI) on return on assets and related party transactions (RPT) on selected firms from Tehran Stock Exchange. Using historical information of selected firms on Tehran Stock Exchange, the study has detected a positive relationship between HHI and RPT and a negative relationship between ROA and HHI. Chen et al. (2012) also reported similar positive results between HHI and RPT.

\section{Acknowledgement}

The authors would like to thank the anonymous referees for constructive comments on earlier version of this paper.

\section{References}

Brickley, J.A., Coles, J.L., \& Jarrell, G. (1997). Leadership structure: separating the CEO and chairman of the board. Journal of Corporate Finance, 3, 189-220.

Cheung, Y. L., Jing, L., Lu, T., Rau, P. R., \& Stouraitis, A. (2009). Tunneling and propping up: An analysis of related party transactions by Chinese listed companies. Pacific-Basin Finance Journal, 17(3), 372-393.

Chen, S., Wang, K., \& Li, X. (2012). Product market competition, ultimate controlling structure and related party transactions. China Journal of Accounting Research, 5(4), 293-306.

Chien, C. Y., \& Hsu, J. (2010). The role of Corporate Governance in related party transactions. Available at SSRN 1539808.

Fama, E.F., \& Jensen, M.C. (1983). Separation of ownership and control. Journal of Law and Economics, 26, 301-325.

Hwang, N. C. R., Chiou, J. R., \& Wang, Y. C. (2013). Effect of disclosure regulation on earnings management through related-party transactions: Evidence from Taiwanese firms operating in China. Journal of Accounting and Public Policy, 32(4), 292-313.

Jensen, M.C. (1993). Presidential Address: the modern industrial revolution, exit and the failure of internal control systems. Journal of Finance, 48, 831 - 880. 
Kang, M., Lee, H. Y., Lee, M. G., \& Park, J. C. (2014). The association between related-party transactions and control-ownership wedge: Evidence from Korea. Pacific-Basin Finance Journal, 29, 272-296.

Phillips, P. C., \& Perron, P. (1988). Testing for a unit root in time series regression. Biometrika, 75(2), 335-346.

Yeh, Y. H., Shu, P. G., \& Su, Y. H. (2012). Related-party transactions and corporate governance: The evidence from the Taiwan stock market. Pacific-Basin Finance Journal, 20(5), 755-776. 